\title{
Cribriform glands are associated with worse outcome than other pattern 4 subtypes: A study of prognostic and clinicopathologic characteristics of prostate adenocarcinoma with an emphasis on
} grade groups

\author{
Eylul Gun ${ }^{1}$ and Irfan Ocal ${ }^{1}$ \\ ${ }^{1}$ Izmir Katip Celebi University
}

May 28, 2021

\begin{abstract}
Aim: Although prostate adenocarcinoma is the most common cancer in men, survival is quite high and with the help of histopathological examination using the updated classification, patient management strategies are developing. We aimed to evaluate the correlation between the histopathological features and biochemical recurrence (BCR) in patients who underwent radical prostatectomy $(\mathrm{RP})$ using the new classification. Methods: A total of 285 prostate adenocarcinoma cases that underwent RP between January 2009 and December 2017 and followed up for at least 3 months were included in the study. The cases were re-evaluated according to WHO-ISUP 2016 classification and the findings were recorded. Results: The mean age was 63,4 years. Gleason scores of the cases were as follows: $3+3144$ cases $(50.5 \%), 3+481$ cases $(28.4 \%), 4+328$ cases (9.8\%), $4+47$ cases $(2.5 \%), 3+56$ cases $(2.1 \%), 5+32$ cases $(0.7 \%), 4+517$ cases $(6 \%)$. There were $198(69,5 \%)$ pT2, 54 (18,9\%) pT3a and $33(11,6 \%)$ pT3b cases. The mean follow-up time was 44,1 months and BCR was detected in 97 cases (34\%). The relationship between the Group Grades and BCR was statistically significant. BCR rate increased as the tumor volume and the percentage of pattern 4 increased $(\mathrm{p}<0.001)$. There was a significant correlation between preoperative PSA value, extraprostatic extension, seminal vesicle invasion, surgical margin positivity, tumor volume, pattern 4 percentage, presence of cribriform glands and $\mathrm{BCR}$ and recurrence-free survival in both univariate and multivariate analysis and recurrence-free survival was also affected by these parameters. Among the morphological subtypes of Pattern 4, recurrence-free survival decreased as the incidence of cribriform glands increased ( $\mathrm{p}<0.001$ ). Conclusion: Histopathological evaluation is important in predicting BCR in prostate adenocarcinoma, the Group Grade system seems to be helpful in this regard. More studies are needed to prove the relatively worse prognostic effect of cribriform glands.
\end{abstract}

\section{INTRODUCTION}

Prostate adenocarcinoma is the most common cancer in men and the second cause of mortality after lung cancer (1). The fact that the tumor has different growth rates in different histopathological (HP) patterns and its mortality is relatively low reveal the importance of the HP examination in terms of treatment modalities.

The Gleason scoring system, which was first developed by Donald Gleason in 1966 and universally accepted in 1974, has been updated over the years, but is still valid today and is seen as the most valuable prognostic parameter of prostate cancer (2-4). In recent studies, it was found that the prognoses of scores such as $3+4$ and $4+3$, which have the same sum but a different order of pattern frequencies, have been found to be different and this system has been updated. The latest classification which was published by the World Health Organization (WHO) in 2016, includes a consensus approach between the WHO and The International Urological Pathology Association (ISUP) after a meeting which was held in 2014 (5,6). According to this consensus report, Gleason score (GS) 2-5 were not included in this staging due to the difficulty in diagnosis, 
tumors with a GS $3+3=6$ were classified as Group Grade (GG) I, tumors with $3+4=7$ as GG II, tumors with $4+3=7$ are classified as GG III, tumors with $4+4=8,3+5=8$, and $5+3=8$ as GG IV and GS 9 - 10 are classified as GG V (6-8).

In addition to the GS, the HP parameters that are thought to affect prognosis include extraprostatic extension (EPE), surgical margin positivity (SMP), perineural invasion (PNI), lymphovascular invasion (LVI), seminal vesicle invasion (SVI), presence of a high-grade tertiary pattern and high grade prostatic intraepithelial neoplasia (HGPIN). While some of these have proven prognostic effects, some of them remain to be controversial $(9,10)$. Besides, studies are reporting that the presence of cribriform type glands in the Gleason pattern 4 group has a worse prognosis than other pattern 4 histological subtypes (11-14).

Prostate-specific antigen (PSA) values in blood are used to determine the biochemical recurrence (BCR) in the postoperative period and it is also important in evaluating treatment response $(15,16)$. Patients with a high GS are likely to show recurrence, but these criteria have not been clearly defined $(6,8)$.

Based on all these information and updates, we aimed to revise the HP findings of radical prostatectomy (RP) materials according to the WHO-ISUP 2016 classification, to determine the BCRs of these patients in the postoperative period, and try to establish a correlation between the recurrent patients and HP features, to compare the new classification with the old one and to investigate the effects of the evaluated HP features in terms of recurrence and prognosis.

\section{MATERIAL AND METHODS}

A total of 318 patients who underwent RP with the diagnosis of prostate adenocarcinoma in Izmir Katip Celebi University Ataturk Training and Research Hospital between January 2009 and December 2017 were retrospectively analyzed through the hospital system. Ethics committee approval was obtained from the Non-Invasive Research Ethics Committee of Izmir Katip Celebi University.

The age, gender, preoperative biopsy results, the operation date, postoperative follow-up time, and the latest data regarding their survival were taken from the hospital system and the National Death Database. Preoperative and postoperative serum PSA values of the cases, the time from surgery to recurrence in patients with recurrence in PSA values, and treatment protocols applied to the patients were examined and recorded.

All H\&E stained slides prepared from the tissues fixed with $10 \%$ formaldehyde solution and embedded in paraffin blocks were obtained from the Pathology Clinic slide storage and re-evaluated according to the Modified WHO-ISUP 2016 classification under the microscope. GSs of the cases, GG categories, HP patterns, and the percentage of these patterns, the presence of EPE, SMP, LVI, PNI, HDPIN, and tertiary patterns were evaluated and recorded. According to AJCC TNM 8th edition, pathological stages of the cases were classified as pT2, pT3a, and pT3b.

Thirty-three patients who did not come to the hospital for postoperative follow-up and were not followed up for at least 3 months or did not have two consecutive serum PSA values were excluded from the study.

Statistical analysis

Overall survival was expressed as the time from the moment of diagnosis to the death of the patient or the last follow-up period, and recurrence-free survival (RFS) was expressed as the time from the moment of diagnosis until the BCR which means the PSA values were detected above [?]0.2 ng/ml in two separate measurements in the postoperative period or the death of the patients. All data were summarized as numbers and percentages for statistical analysis. The HP features and clinical and prognostic data obtained were compared. In the statistical analysis of the data, "SPSS 24.0 for Windows" (IBM, Chicago, IL, USA) program was used. While evaluating the study data, besides descriptive statistical methods (mean, standard deviation), the chi-square test was used to examine the relationship between parametric values in comparison of categorical data, and Fisher exact test was used to compare two non-parametric groups. Mann Whitney U test was used for the analysis of variables that did not show normal distribution. Logistic regression analysis was used for the 
rate at which the independent variables affect the dependent variable. Kaplan-Meier analysis was used to calculate survival probabilities. Results were analyzed at a 95\% confidence interval. p[?]0.05 was considered as statistically significant.

\section{RESULTS}

\section{Patient selection and demographic data}

There were 318 patients diagnosed with prostate cancer in our department after RP between January 2009 and December 2017. In the postoperative follow-up studies carried out within the hospital system, a total of 33 cases who were not followed up or followed for less than 3 months were excluded from the study. All evaluations were made with the remaining 285 cases. The ages varied between $45-84$ and the mean age was $63.48( \pm 6.72)$.

\section{Histopathological findings}

The distribution of 285 cases evaluated according to RP GSs and GGs are given in Table 1. There were no cases with GSs $5+4$ and $5+5$. The comparison between biopsy GSs and RP GSs is given in Table 2. Mean tumor volume was calculated as $8 \%$ (IQR: $5-17)$. While the tumor was unilaterally located in $64(22.4 \%)$ patients (left prostate 34 cases, right prostate 30 cases), in $221(77.6 \%)$ patients the tumor infiltrated both lobes. The distribution of the cases according to the pathological stages was found as $198(69.5 \%)$ cases in the pT2 category, $54(18.9 \%)$ cases in the pT3a category, and $33(11.6 \%)$ cases in the pT3b category.

Considering HP patterns, well-formed glands were observed in all 144 (50.5\%) GS 3+3 (GG I) cases. The distribution of different histomorphological appereances seen in Gleason pattern 4 (Figure 1) and the ones seen in Gleason pattern 5 (Figure 2) is shown in Table 3. The foamy variant was seen in $43(15.1 \%)$ cases, the most frequent one being GS $3+4$ and secondly $4+3$, while the pure form was observed only in 5 cases with GS $3+3$ tumors (Table 1 ).

\section{Clinical findings}

The follow-up period of the cases ranged from 3-108 months, and the mean follow-up period was 44.19 $( \pm 30.2)$ months. The mean preoperative PSA value of the cases was $7.8(2.18-61) \mathrm{ng} / \mathrm{ml}$ (IQR:5.5-12.3). The mean postoperative PSA value was $0.07 \mathrm{ng} / \mathrm{ml}$ (IQR:0.03-0.25).

BCR was accepted as the patients having a PSA value of $>0.2 \mathrm{ng} / \mathrm{ml}$ in two consecutive measurements in the postoperative period. The number of patients with BCR was 97 (34\%). The mean preoperative PSA value of these patients was $14.6 \mathrm{ng} / \mathrm{ml}$ and the mean postoperative PSA value was $0.61 \mathrm{ng} / \mathrm{ml}$. When these patients were evaluated in terms of RP GS, $17(11.8 \%)$ of the patients in GG I, $33(40.7 \%)$ in GG II, $20(71.4 \%)$ in GG III, $11(73.3 \%)$ in GG IV and $16(94.1 \%)$ in GG V category had BCR. The relationship between RP GGs and BCR was statistically significant $(\mathrm{p}<0.001)$. As the GGs of the cases increased, the rate of BCR increased.

The mean time to BCR was calculated as 4 (IQR:3-18) months. It was found that $34(35 \%)$ of the patients with BCR were treated with hormonotherapy, 57 (58.8\%) with local radiotherapy, and $6(6.2 \%)$ with chemotherapy. In the follow-up, while $256(89.8 \%)$ of the patients were still alive, $29(10.2 \%)$ died. In terms of the cause of death, the patients were divided into two groups as death due to prostate cancer (bone metastasis, radiotherapy/chemotherapy complications, etc.) and death from causes other than prostate cancer. There were $6(2.1 \%)$ patients in the first group. The mean preoperative PSA values of these patients were 19.2 $\mathrm{ng} / \mathrm{ml}$. GSs were $3+5$ in 3 and $4+5$ in the other 3 patients. It was found that bone metastasis developed in all patients and related complications occurred. Postoperative follow-up time (from diagnosis to death) was 42 months on average. There were $23(8.1 \%)$ patients who died from causes other than prostate cancer.

\section{Biochemical recurrence analysis}

No significant relationship was found between the age of the patients and $\mathrm{BCR},(\mathrm{p}=0.974)$. The relationship between the preoperative PSA values and BCR status was significant $(\mathrm{p}<0.001)$. While the median preope- 
rative PSA value was $10(6.7-19.4) \mathrm{ng} / \mathrm{ml}$ in patients with BCR, it was found as 6.7 (IQR:5-9.89) ng/ml in patients without BCR.

In terms of HP evaluation and BCR status, a statistically significant correlation was found between the presence of EPE, SMP, PNI, LVI, SVI, and BCR ( $\mathrm{p}<0.001)$. There was no statistically significant relationship between the presence of HGPIN and the presence of a high-grade tertiary pattern and BCR $(\mathrm{p}>0.05)$. In the subsequent multivariate analyzes, EPE, SMP, and SVI preserved their significance $(\mathrm{p}<0.001)$ (Table 4).

The tumor volume and BCR showed a statistically significant relationship $(\mathrm{p}<0.001)$. While the median tumor volume was 10\% (IQR:6.7-19) in patients with BCR, it was 7\% (IQR:4-12) in the others. Pattern 4 percentage and $\mathrm{BCR}$ also showed a significant relationship $(\mathrm{p}<0.001)$. While the median pattern 4 percentage was 45\% (IQR:25-70) in patients with BCR, it was 18\% (IQR:10-20) in the others. The rate of BCR increased significantly as the pathological stage increased $(\mathrm{p}<0.001)$.

In the univariate analyses according to HP patterns, the morphologies of fused glands, cribriform glands, cribriform glands with comedonecrosis, sheets/cords, solid areas, and single-cell infiltration was found to be statistically significant in terms of BCR $(\mathrm{p}<0.001)$. In the subsequent multivariant analyzes, the fused gland, cribriform gland, layers/cords, and solid area morphologies preserved their significance $(\mathrm{p}=0.043, \mathrm{p}<0.001$, $\mathrm{p}<0.001, \mathrm{p}=0.001)$ (Table 3).

\section{Survival analysis}

In the survival analysis, median survival could not be reached as at least $50 \%$ of the patients did not die in the overall survival calculation. From the available data, it was concluded that $77.6 \%$ of the patients $(95 \%$ CI:77.50-77.69) had an overall survival longer than 95 months. The RFS time of the patients was calculated as 107 months on average. There was no significant relationship between patient age and RFS ( $>>0.05)$.

When the effect of GSs and GGs on overall survival was investigated, no statistical significance was found $(\mathrm{p}>0.05)$, however, the effect on RFS was statistically significant $(\mathrm{p}<0.001)$. The survival curves for these results are given in Figure 3.

The median survival of the patients in the pT2 stage was 107 months, $50.8 \%$ of those in the pT3a stage had a survival of $81 \pm 0.2$ months, and the survival of $81 \%$ of those in the pT3b stage was $50 \pm 0.1$ months. The pathological stage showed a statistically strong and significant relationship with RFS (Figure 4).

As for the effect of HP evaluation results on RFS; a statistically significant correlation was found between the presence of EPE, PNI, LVI, SMP, tumor volume, and RFS $(\mathrm{p}<0.001)$, but not with the presence of HGPIN ( $>0.05)$. HP evaluation results and RFS curves are given in Figure 5. In the evaluations made according to the HP patterns, the relationship between the presence of the cribriform glands, a morphological subtype of pattern 4 , and RFS was found to be statistically significant $(\mathrm{p}<0.001)$. RFS decreased as the incidence of cribriform glands increased. The relationship curve between the presence of the cribriform glands and RFS is given in Figure 6.

\section{DISCUSSION}

Prostate adenocarcinoma is the most common cancer in men and the second most common cause of mortality after lung cancer. According to 2020 cancer statistics data of the American Cancer Society, prostate cancer constitutes 1 out of every 5 newly diagnosed cancers in men. Among all cancers, it has the highest survival rate with $98 \%$. The reason behind the increased incidence of prostate cancer in recent years is thought to be the start of PSA screening (1).

Almost $75 \%$ of the patients diagnosed with prostate cancer are 65 years and older, but it can also be seen in younger people (17). The average age in our study was $63.48( \pm 6.72)$.

The correlation between the biopsy GS and the RP GS matters because it affects the treatment method and consequently the prognosis. In the study by Khoddami et al., the biopsy GSs and the RP GSs were the same in $68.2 \%$ of the cases, while 1 or 2 GSs differed in $31.8 \%$. The cases had a lower grade in RP in $9.1 \%$ 
whereas $22.7 \%$ had a higher grade (18). In another similar study, there was a $36.7 \%$ discordance between the scores. It was concluded that the causes of this discordance may be prevented by taking bigger biopsies (19). Our study revealed a similar result with $61.4 \%$ of the cases having the same biopsy and RP scores with a higher RP score in $31.2 \%$ and a lower RP score in 7.4\%. According to WHO-ISUP 2016 classification, it has been argued that Gleason scores 2-5 should not be used anymore due to reasons such as incompatibility between pathologists, the percentage of diagnosis being very low, and the difference between biopsy and RP diagnoses (6).

In the light of new studies that put forth different prognostic results, a new additional GG system has been introduced while the Gleason scoring basically continues with a few HP changes (5-7). With the introduction of the GG system, prognostic research has gained momentum. Mathieu et al. tried to reveal the prognostic value of the new system in a large series of 27122 patients. According to this series, the predicted 4-year RFS for GG I-V was $96.1 \%, 86.7 \%, 67.0 \%, 63.1 \%$ and $41.0 \%$, respectively. Although there was no clinical difference in the created multivariate prognostic models, it was stated that the new system could help clinicians and patients to predict the severity of the disease and was easy to use (20). In the study by Epstein et al., great differences were found in terms of recurrence rates between GSs $3+4$ and $4+3$ and GSs 8 and 9 . It was concluded that the 5-tier GG system was able to make the best prognostic distinction in both univariate and multivariate models (21). In our study, when the relationship between the presence of BCR and GGs was investigated, the rate of recurrence from GG I to $\mathrm{V}$ was $11.8 \%, 40.7 \%, 71.4 \%, 73.3 \%$, and $94.1 \%$, respectively. This increase was statistically significant $(\mathrm{p}<0.001)$ which supports the results of Epstein et al.

The recurrence of prostate cancer after RP is screened by the increase in PSA levels and The American Urological Association has recommended accepting the presence of BCR when two consecutive serum PSA values are [?]0.2 $\mathrm{ng} / \mathrm{ml}$. It has been stated that an increase in serum PSA values above this level does not clinically indicate metastatic disease, but it shows disease progression, and follow-up and additional examinations are required to determine clinically metastatic disease $(22,23)$.

In a study of 305 patients investigating the effect of patient age on BCR after RP, no significant relationship was found between age and recurrence (24). Besides, Kunz et al. evaluated the tumor characteristics of patients over the age of 70, which showed that patients in this age group had more biologically aggressive tumors than younger patients, but age alone was not an independent marker of survival after RP (25). Also in our study, no significant relationship was found between age and BCR, and RFS $(\mathrm{p}=0.974)$.

Besides GS, some of the HP patterns that have been investigated in terms of their prognostic effects include the presence of EPE, PNI, SVI, LVI, SMP, HGPIN, and tertiary pattern. EPE is an important HP parameter that increases the pathological T stage of the tumor to 3a (26). Ball et al. found that EPE has a significant effect on RFS. They also divided EPE into focal and non-focal groups and concluded that focal ones had worse survival. On top of that, they argued that the pT3a category should also be separated in the future (27). In another study conducted with similar criteria, it was stated that EPE is a significant independent factor in showing BCR in multiple analyzes, and the determination of EPE severity may have positive effects on survival (28). In our study, EPE was detected in 81 (28.4\%) patients, and BCR was observed in 44. The relationship between EPE and BCR was statistically significant in single and multiple analyzes $(\mathrm{p}<0.001)$ and the presence of EPE was also found to be effective in RFS $(\mathrm{p}<0.001)$.

Tumors with SVI are evaluated in the pT3b category and SVI is among the most important determinants of cancer-specific survival, together with the pathological stage after RP (29). Although the number of pT3b tumors has been decreasing with early diagnosis and treatment, SVI is still known to be associated with poor prognostic results (30). The fact that BCR was detected in 29 of 33 (11.5\%) cases with SVI in our study proves the bad prognostic effect of SVI.

Although SMP is known to be a predictor of recurrence, it is not certain whether it is a significant indicator of increased risk in cancer-specific mortality (31). In a recent meta-analysis, it was stated that SMP increases the recurrence rate and is an independent prognostic factor (32). The importance of specifying surgical margin positive areas when reporting is not yet known, however, it is among the recommendations to give 
the length of these areas (33). In our study, SMP was detected in 142 (49.8\%) cases, and BCR was observed in 74 of them. The relationship between SMP and BCR was significant in both univariate and multivariate analyzes, and it also had a significant effect on RFS $(\mathrm{p}<0.001)$.

PNI is seen in most of the RP cases and studies have conflicting results about its importance. Merrilees et al. did not find the presence of PNI associated with survival after RP, so they did not recommend it to be reported (34). On the other hand, Reeves et al. found that patients with PNI had higher GS, more pT3 disease, more SMP and higher tumor volume, and emphasized the need for more studies to understand the biological behavior of PNI (35). Loeb et al. stated that PNI is an independent risk factor for aggressive pathological features and a dependent risk factor for BCR (36). In our study, PNI was seen in 176 (61.7\%) cases, and BCR was observed in 75 of these cases. Although it seemed significant for BCR in univariate analyzes $(\mathrm{p}<0.001)$, it was not significant in multiple analyzes $(\mathrm{p}=0.382)$.

LVI has been determined as an independent determinant affecting patient survival in a few studies, however, it has been concluded that LVI is not sufficient to show BCR due to insufficient homogeneity in more detailed studies (37). Since it is known that the surrounding stromal tissue can mimic vascular invasion, it is predicted that the evaluation of LVI between pathologists may be different in most studies. Huang et al. concluded that it is an independent prognostic factor in predicting BCR (38). In our study, LVI was observed only in $23(8 \%)$ cases, and BCR was detected in 19 of them. Although it was significant for recurrence in univariate analyzes $(\mathrm{p}<0.001)$, it was not significant in multivariate analyzes $(\mathrm{p}=0.160)$.

HGPIN is seen as a precursor of prostate cancer. In a study investigating the presence of HGPIN around cancer areas and its importance in RPs, it was observed in $58 \%$ of the cases, and it was found that the cancers associated with HGPIN had a better GS, lower PSA value, lower tumor volume and better survival (39). In our study, HGPIN was detected in 183 (64.2\%) cases, and it was noteworthy that 86 of these cases had a GS of $3+3$, and 61 of them had $3+4$. These results support the hypothesis that HGPIN is seen with lower GSs.

The presence of a tertiary pattern reflects aggressive pathological features that show advanced pathological stage and reduced RFS, especially in Gleason score $3+4$ and $4+3$ tumors (40). Ozsoy et al. found that the cases with a tertiary pattern have a worse prognosis compared to the cases with the same GS without a tertiary pattern (41). In our study, high-grade tertiary pattern was observed only in $19(6.7 \%)$ cases, and it was not statistically significant in terms of BCR ( $>>0.05)$.

The results of the studies evaluating the prognostic significance of tumor volume are contradictory. Although tumor volume is known to be associated with pathological stage, studies have not yet shown that it is an independent determinant for survival (42). In a study, it was found that increased tumor volume was associated with SVI, SMP, and lymph node involvement, and it was stated that the increase in tumor volume could be considered as a risk factor after RP (43). In our study, a significant relationship was found between tumor volume and BCR $(\mathrm{p}<0.001)$. It was thought that the presence of recurrence in patients with low GS and a low expectation of BCR may be due to the high tumor volume, and the absence of recurrence in patients with high GS and expected BCR may be associated with the tumor volume being $5 \%$ or less.

The foamy variant prostate adenocarcinoma, which was seen with a GS of $3+4$ in 28 cases and a $4+3$ GS in 6 cases in our study, is a subtype with a similar prognosis with the non-foamy type, usually associated with a GS of 7 and pattern 4 (44). Due to the difficulty of its diagnosis, attention should be paid especially in tumors with pattern 4. We couldn't find a significance in terms of BCR ( $\mathrm{p}>0.05)$.

$\mathrm{RP}$ is still the accepted approach and the ideal treatment for disease-free survival in eligible patients. In their study, Lughezzani et al. stated that even in patients with high-grade cancer with a GS of 8 and above, if the cancer is limited to the organ, long-term oncologic results are quite good (45). Active surveillance is an issue that has been suggested for low-risk, localized prostate cancer, and has been discussed for years. With the increase in early-stage prostate cancer cases as a result of the widespread use of PSA screenings, active surveillance is on the agenda for patients with a GS of 6 and PSA values of $<10 \mathrm{ng} / \mathrm{ml}$, by digital rectal examination, periodic biopsies, and serial PSA measurements. It has been shown that this approach 
is reliable in the long term with the right patient selection, with a cancer-specific mortality rate of $3 \%$ in the 10th to 15 th years (46). BCR was detected in only 17 of 144 GG I cases with a $3+3$ GS in our study, and SMP was observed in 14 of these recurrent cases and inadequate surgery was considered as the reason for recurrence. These data in our study support active surveillance in appropriate and properly selected patients, due to the high levels of RFS in $3+3$ patients.

In the latest WHO-ISUP classification, it was recommended to indicate the percentage of pattern 4 in $3+4$ and $4+3$ cases with a GS of 7 , as it plays a role in patient management strategies and active surveillance (6). In a study investigating the effect on RFS by dividing the percentage of pattern 4 into 3 groups (21-50\%, $51-70 \%$, [?]70\%), pattern 4 percentage was found to be an independent predictor of RFS (47). In our study, the median of pattern 4 was found to be $45 \%$ in patients with recurrence and $18 \%$ in patients without recurrence, and it was found to be associated with RFS $(\mathrm{p}<0.05)$. In the latest Genitourinary Pathology Society (GUPS) White Paper, the preferred method of reporting Gleason pattern 4 percentage was suggested to be either [?] $5 \%$ or [?] $10 \%$ and $10 \%$ increments thereafter for GGs 2 and 3 (48).

In the latest studies that investigate the different morphological subtypes of Gleason pattern 4, it was reported that cribriform type glands have a worse prognostic outcome in terms of BCR compared to other pattern 4 types (14). In their study in 2015, Kweldam et al. showed that cribriform morphology is a very good predictor of postoperative metastasis and disease-related mortality in tumors with a GS of 7, and in another study in 2017, they found that invasive cribriform and/or intraductal carcinoma after RP was an independent parameter in determining RFS $(11,49)$. Similarly, Choy et al. observed that the presence of cribriform architecture in patients with GS 7 cancer was associated with a reduced 5-year RFS (47). Bottcher et al. found that cribriform and intraductal prostate cancer have increased genomic instability and genomic alterations, and therefore show poor prognostic effects (12). In the GUPS white paper, it was suggested to report the presence or absence of cribriform glands in Gleason pattern 4 (48). After the $3+3$ GS cases with BCR detected only in $11.8 \%$, pattern 4 was evaluated in our study according to 4 different histological subtypes. Cribriform glands were observed in 64 cases with Gleason pattern 4 . The presence of cribriform glands was statistically significant in terms of BCR in both univariate and multivariate analyzes $(\mathrm{p}<0.001)$ and in survival analysis, it was found to be significantly associated with RFS $(\mathrm{p}<0.001)$. These results are consistent with the literature and show that cribriform glands have a worse prognostic outcome than other pattern 4 subtypes.

The strong point of our study is the extensive and detailed examination of HP parameters and the patient follow-up data. The limitations are the relatively short median follow-up time and the retrospective design of the study resulting in not being able to perform immunohistochemistry in the discrimination of intraductal carcinoma.

\section{CONCLUSION}

We prove once more that HP evaluation is of great importance in predicting BCR in prostate adenocarcinoma cases. The GG system seems to be helpful in this regard. More HP and molecular studies are needed to prove the relatively worse prognostic effect of cribriform glands.

\section{REFERENCES}

1. Siegel RL, Miller KD, Jemal A. Cancer statistics, 2020. CA Cancer J Clin. 2020;70(1):7-30.

2. Gleason DF. Classification of prostatic carcinomas. Cancer Chemother Rep. 1966;50(3):125-8.

3. Gleason DF, Mellinger GT, Ardving LJ. Prediction of prognosis for prostatic adenocarcinoma by combined histological grading and clinical staging. J Urol. 1974;111:58-64.

4. Gleason DF. Histologic grading of prostate cancer: A perspective. Hum Pathol. 1992;23:273-9.

5. Epstein JI, Egevad L, Amin MB, Delahunt B, Srigley JR, Humphrey PA. The 2014 international society of urological pathology (ISUP) consensus conference on gleason grading of prostatic carcinoma definition of grading patterns and proposal for a new grading system. Am J Surg Pathol. 2016;40(2):244-52. 
6. Humphrey PA, Moch H, Cubilla AL, Ulbright TM, Reuter VE. The 2016 WHO Classification of Tumours of the Urinary System and Male Genital Organs-Part B: Prostate and Bladder Tumours. Eur Urol. 2016;70(1):106-19.

7. Chen N, Zhou Q. The evolving gleason grading system. Chinese J Cancer Res. 2016;28(1):58-64.

8. Gordetsky J, Epstein J. Grading of prostatic adenocarcinoma: Current state and prognostic implications. Diagn Pathol. 2016;11:25.

9. Hoogland AM, Kweldam CF, Leenders GJLHV. Prognostic Histopathological and Molecular Markers on Prostate Cancer Needle-Biopsies: A Review. BioMed Research International. 2014. p. 2014.

10. Gleason DF, Mellinger GT, Arduino LJ, Bailar JC, Becker LE, Berman HI, et al. Prediction of Prognosis for Prostatic Adenocarcinoma by Combined Histological Grading and Clinical Staging. J Urol. 2017;197(2):134-9.

11. Kweldam CF, Wildhagen MF, Steyerberg EW, Bangma CH, Van Der Kwast TH, Van Leenders GJLH. Cribriform growth is highly predictive for postoperative metastasis and disease-specific death in Gleason score 7 prostate cancer. Mod Pathol. 2015;28(3):457-64.

12. Bottcher R, Kweldam CF, Livingstone J, Lalonde E, Yamaguchi TN, Huang V, et al. Cribriform and intraductal prostate cancer are associated with increased genomic instability and distinct genomic alterations. BMC Cancer. 2018;18(1):1-11.

13. Hollemans E, Verhoef EI, Bangma CH, Rietbergen J, Helleman J, Roobol MJ, et al. Large cribriform growth pattern identifies ISUP grade 2 prostate cancer at high risk for recurrence and metastasis. Mod Pathol. 2019;32(1):139-46.

14. Kweldam CF, van Leenders GJ, van der Kwast T. Grading of prostate cancer: a work in progress. Histopathology. 2019;74:146-60.

15. Stephenson AJ, Kattan MW, Eastham JA, Dotan ZA, Bianco FJ, Lilja H, et al. Defining biochemical recurrence of prostate cancer after radical prostatectomy: A proposal for a standardized definition. J Clin Oncol. 2006;24(24):3973-8.

16. Lilja H, Ulmert D, Vickers AJ. Prostate-specific antigen and prostate cancer: Prediction, detection and monitoring. Nat Rev Cancer. 2008;8(4):268-78.

17. Mills SE, Greenson JK, Hornick JL, Longacre TA, Reuter VE. Sternberg's diagnostic surgical pathology: Sixth edition. Sternberg's Diagnostic Surgical Pathology: Sixth Edition. 2015. 2097-143 p.

18. Khoddami M, Khademi Y, Aghdam MK, Soltanghoraee H. Correlation between Gleason scores in needle biopsy and corresponding radical prostatectomy specimens: A twelve-year review. Iran J Pathol. 2016;11(2):120-6.

19. Ozturk E, Yikilmaz T. Gleason Score Correlation Between Prostate Biopsy and Radical Prostatectomy Specimens. Bull Urooncol. 2018;17(1):1-4.

20. Mathieu R, Moschini M, Beyer B, Gust KM, Seisen T, Briganti A, et al. Prognostic value of the new grade groups in prostate cancer: A multi-institutional European validation study. Prostate Cancer Prostatic Dis. 2017;20(2):197-202.

21. Epstein JI, Zelefsky MJ, Sjoberg DD, Nelson JB, Egevad L, Magi-Galluzzi C, et al. A Contemporary Prostate Cancer Grading System: A Validated Alternative to the Gleason Score. Eur Urol. 2016;69(3):42835.

22. Cookson MS, Aus G, Burnett AL, Canby-Hagino ED, D'Amico A V., Dmochowski RR, et al. Variation in the Definition of Biochemical Recurrence in Patients Treated for Localized Prostate Cancer: The 
American Urological Association Prostate Guidelines for Localized Prostate Cancer Update Panel Report and Recommendations for a Standard in the Re. J Urol. 2007;177(2):540-5.

23. Tourinho-Barbosa RR, Srougi V, Nunes-Silva I, Baghdadi M, Rembeyo G, Eiffel SS, et al. Biochemical recurrence after radical prostatectomy: What does it mean? Int Braz J Urol. 2018;44(1):14-21.

24. Ozden C, Aktas BK, Bulut S, Erbay G, Tagci S, Gokkaya CS, et al. Effect of age on biochemical recurrence after radical prostatectomy. Kaohsiung J Med Sci. 2017;33(2):91-5.

25. Kunz I, Musch M, Roggenbuck U, Klevecka V, Kroepfl D. Tumour characteristics, oncological and functional outcomes in patients aged [?] 70 years undergoing radical prostatectomy. BJU Int. 2013;111(3):24-9.

26. Fine S. Updates in AJCC/TNM Staging of Prostate Cancer Financial Relationships Summary of changes. In 2017. p. 1-6.

27. Ball MW, Partin AW, Epstein JI. Extent of extraprostatic extension independently influences biochemical recurrence-free survival: Evidence for further PT3 subclassification. Urology. 2015;85(1):161-4.

28. Jeong BC, Chalfin HJ, Lee SB, Feng Z, Epstein JI, Trock BJ, et al. The relationship between the extent of extraprostatic extension and survival following radical prostatectomy. Eur Urol. 2015;67:342-6.

29. Eggener SE, Scardino PT, Walsh PC, Han M, Partin AW, Trock BJ, et al. Predicting 15-year prostate cancer specific mortality after radical prostatectomy. J Urol. 2011;185(3):869-75.

30. Pierorazio PM, Ross AE, Schaeffer EM, Epstein JI, Han M, Walsh PC, et al. A contemporary analysis of outcomes of adenocarcinoma of the prostate with seminal vesicle invasion (pT3b) after radical prostatectomy. J Urol. 2011;185(5):1691-7.

31. Stephenson AJ, Eggener SE, Hernandez A V., Klein EA, Kattan MW, Wood DP, et al. Do margins matter? the influence of positive surgical margins on prostate cancer-specific mortality. Eur Urol. 2014;65:675-80.

32. Zhang L, Wu B, Zha Z, Zhao H, Jiang Y, Yuan J. Positive surgical margin is associated with biochemical recurrence risk following radical prostatectomy: A meta-analysis from high-quality retrospective cohort studies. World J Surg Oncol. 2018;16(1):124.

33. Samaratunga H, Montironi R, True L, Epstein JI, Griffiths DF, Humphrey PA, et al. International society of urological pathology (ISUP) consensus conference on handling and staging of radical prostatectomy specimens. working group 1: Specimen handling. Mod Pathol. 2011;24(1):1-5.

34. Merrilees AD, Bethwaite PB, Russell GL, Robinson RG, Delahunt B. Parameters of perineural invasion in radical prostatectomy specimens lack prognostic significance. Mod Pathol. 2008;21:1095-100.

35. Reeves F, Hovens CM, Harewood L, Battye S, Peters JS, Costello AJ, et al. Does perineural invasion in a radical prostatectomy specimen predict biochemical recurrence in men with prostate cancer? Can Urol Assoc J. 2015;9(5-6):252-5.

36. Loeb S, Epstein JI, Humphreys EB, Walsh PC. Does perineural invasion on prostate biopsy predict adverse prostatectomy outcomes? BJU Int. 2010;105(11):1510-3.

37. Ng J, Mahmud A, Bass B, Brundage M. Prognostic significance of lymphovascular invasion in radical prostatectomy specimens. BJU Int. 2012;110:1507-14.

38. Huang Y, Huang H, Pan XW, Xu DF, Cui XG, Chen J, et al. The prognostic value of lymphovascular invasion in radical prostatectomy: A systematic review and meta-analysis. Asian J Androl. 2016;18(5):780-5.

39. Eminaga O, Hinkelammert R, Abbas M, Titze U, Eltze E, Bettendorf O, et al. High-grade prostatic intraepithelial neoplasia (HGPIN) and topographical distribution in 1,374 prostatectomy specimens: Existence of HGPIN near prostate cancer. Prostate. 2013;73(10):1115-22. 
40. Whittemore DE, Hick EJ, Carter MR, Moul JW, Miranda-Sousa AJ, Sexton WJ. Significance of tertiary Gleason pattern 5 in Gleason score 7 radical prostatectomy specimens. J Urol. 2008;179(2):516-22.

41. Ozsoy M, D'Andrea D, Moschini M, Foerster B, Abufaraj M, Mathieu R, et al. Tertiary Gleason pattern in radical prostatectomy specimens is associated with worse outcomes than the next higher Gleason score group in localized prostate cancer. Urol Oncol Semin Orig Investig. 2018;36(4):158.e1-158.e6.

42. Epstein JI. Prognostic significance of tumor volume in radical prostatectomy and needle biopsy specimens. J Urol. 2011;186(3):790-7.

43. Knoedler JJ, Karnes RJ, Thompson RH, Rangel LJ, Bergstralh EJ, Boorjian SA. The association of tumor volume with mortality following radical prostatectomy. Prostate Cancer Prostatic Dis. 2014;17(2):144-8.

44. Hudson J, Cao D, Vollmer R, Kibel AS, Grewal S, Humphrey PA. Foamy gland adenocarcinoma of the prostate: Incidence, Gleason grade, and early clinical outcome. Hum Pathol. 2012;43(7):975-9.

45. Lughezzani G, Gallina A, Larcher A, Briganti A, Capitanio U, Suardi N, et al. Radical prostatectomy represents an effective treatment in patients with specimen-confined high pathological Gleason score prostate cancer. BJU Int. 2013;111(5):723-30.

46. Garisto JD, Klotz L. Active Surveillance for Prostate Cancer: How to Do It Right. Oncology (Williston Park). 2017;31(5):333-40, 345.

47. Choy B, Pearce SM, Anderson BB, Shalhav AL, Zagaja G, Eggener SE, et al. Prognostic significance of percentage and architectural types of contemporary gleason pattern 4 prostate cancer in radical prostatectomy. Am J Surg Pathol. 2016;40(10):1400-6.

48. Epstein JI, Amin MB, Fine SW, Algaba F, Aron M, Baydar DE, et al. The 2019 Genitourinary Pathology Society (GUPS) White Paper on Contemporary Grading of Prostate Cancer. Arch Pathol Lab Med. 2020;

49. Kweldam CF, Kummerlin IP, Nieboer D, Steyerberg EW, Bangma CH, Incrocci L, et al. Presence of invasive cribriform or intraductal growth at biopsy outperforms percentage grade 4 in predicting outcome of Gleason score $3+4=7$ prostate cancer. Mod Pathol. 2017;30:1126-32.

Funding: None

Acknowledgements: This study has been presented as a poster in the 2020 ESP\&IAP Glasgow Congress held virtually.

Table 1. Demographic, clinical and histopathological characteristics of 285 radical prostatectomy cases.

\begin{tabular}{|c|c|c|c|c|c|c|c|c|}
\hline $\begin{array}{l}\text { GROUP } \\
\text { GRADE }\end{array}$ & $\begin{array}{l}\text { GROUP } \\
\text { GRADE }\end{array}$ & $\begin{array}{l}\text { GROUP } \\
\text { GRADE I }\end{array}$ & $\begin{array}{l}\text { GROUP } \\
\text { GRADE } \\
\text { II }\end{array}$ & $\begin{array}{l}\text { GROUP } \\
\text { GRADE } \\
\text { III }\end{array}$ & $\begin{array}{l}\text { GROUP } \\
\text { GRADE } \\
\text { IV }\end{array}$ & $\begin{array}{l}\text { GROUP } \\
\text { GRADE } \\
\text { IV }\end{array}$ & $\begin{array}{l}\text { GROUP } \\
\text { GRADE } \\
\text { IV }\end{array}$ & $\begin{array}{l}\text { GROUP } \\
\text { GRADE } \\
\mathrm{V}\end{array}$ \\
\hline $\begin{array}{l}\text { GLEASON } \\
\text { SCORE }\end{array}$ & $\begin{array}{l}\text { GLEASON } \\
\text { SCORE }\end{array}$ & $3+3$ & $3+4$ & $4+3$ & $3+5$ & $5+3$ & $4+4$ & $4+5$ \\
\hline $\begin{array}{l}\text { Age } \\
\text { (years) }\end{array}$ & Median & 63 & 64 & 63 & 62 & 58 & 62 & 67 \\
\hline & Range & $45-83$ & $48-77$ & $51-72$ & $47-67$ & $45-71$ & $50-71$ & $53-84$ \\
\hline \multirow{2}{*}{$\begin{array}{l}\text { PSA } \\
(\mathrm{ng} / \mathrm{ml})\end{array}$} & Median & 7,72 & 11,9 & 14,7 & 17,8 & 8,25 & 20,1 & 19 \\
\hline & Range & $2,8-36$ & $2,3-51$ & $3,3-43$ & $\begin{array}{l}2,2- \\
38,9\end{array}$ & $7,5-9$ & $2,2-61$ & $6,3-55$ \\
\hline $\begin{array}{l}\text { pT } \\
\text { Stage }\end{array}$ & pT2 & $\begin{array}{l}125 \\
(63,1 \%)\end{array}$ & $\begin{array}{l}50 \\
(25,2 \%)\end{array}$ & $\begin{array}{l}10 \\
(5,0 \%)\end{array}$ & $\begin{array}{l}2 \\
(1,0 \%)\end{array}$ & $\begin{array}{l}2 \\
(1,0 \%)\end{array}$ & $\begin{array}{l}5 \\
(2,5 \%)\end{array}$ & $\begin{array}{l}4 \\
(2,0 \%)\end{array}$ \\
\hline
\end{tabular}




\begin{tabular}{|c|c|c|c|c|c|c|c|c|c|}
\hline $\begin{array}{l}\text { GROUP } \\
\text { GRADE }\end{array}$ & $\begin{array}{l}\text { GROUP } \\
\text { GRADE }\end{array}$ & $\begin{array}{l}\text { GROUP } \\
\text { GRADE I }\end{array}$ & $\begin{array}{l}\text { GROUP } \\
\text { GRADE } \\
\text { II }\end{array}$ & $\begin{array}{l}\text { GROUP } \\
\text { GRADE } \\
\text { III }\end{array}$ & $\begin{array}{l}\text { GROUP } \\
\text { GRADE } \\
\text { IV }\end{array}$ & $\begin{array}{l}\text { GROUP } \\
\text { GRADE } \\
\text { IV }\end{array}$ & $\begin{array}{l}\text { GROUP } \\
\text { GRADE } \\
\text { IV }\end{array}$ & $\begin{array}{l}\text { GROUP } \\
\text { GRADE } \\
\mathrm{V}\end{array}$ & \\
\hline & pT3a & $\begin{array}{l}18 \\
(33,3 \%)\end{array}$ & $\begin{array}{l}21 \\
(38,8 \%)\end{array}$ & $\begin{array}{l}6 \\
(11,1 \%)\end{array}$ & $\begin{array}{l}2 \\
(3,7 \%)\end{array}$ & $\begin{array}{l}0 \\
(0,0 \%)\end{array}$ & $\begin{array}{l}2 \\
(3,7 \%)\end{array}$ & $\begin{array}{l}5 \\
(9,2 \%)\end{array}$ & \\
\hline & pT3b & $\begin{array}{l}1 \\
(3,0 \%)\end{array}$ & $\begin{array}{l}10 \\
(30,3 \%)\end{array}$ & $\begin{array}{l}12 \\
(36,3 \%)\end{array}$ & $\begin{array}{l}2 \\
(6,0 \%)\end{array}$ & $\begin{array}{l}0 \\
(0,0 \%)\end{array}$ & $\begin{array}{l}0 \\
(0,0 \%)\end{array}$ & $\begin{array}{l}8 \\
(24,2 \%)\end{array}$ & \\
\hline \multirow[t]{2}{*}{ SMP } & Yes & $\begin{array}{l}47 \\
(33,1 \%)\end{array}$ & $\begin{array}{l}52 \\
(36,6 \%)\end{array}$ & $\begin{array}{l}20 \\
(14,1 \%)\end{array}$ & $\begin{array}{l}2 \\
(1,4 \%)\end{array}$ & $\begin{array}{l}4 \\
(2,8 \%)\end{array}$ & $\begin{array}{l}2 \\
(1,4 \%)\end{array}$ & $\begin{array}{l}15 \\
(10,6 \%)\end{array}$ & \\
\hline & No & $\begin{array}{l}97 \\
(67,8 \%)\end{array}$ & $\begin{array}{l}29 \\
(20,3 \%)\end{array}$ & $\begin{array}{l}8 \\
(5,6 \%)\end{array}$ & $\begin{array}{l}5 \\
(3,5 \%)\end{array}$ & $\begin{array}{l}2 \\
(1,4 \%)\end{array}$ & $\begin{array}{l}0 \\
(0,0 \%)\end{array}$ & $\begin{array}{l}2 \\
(1,4 \%)\end{array}$ & \\
\hline \multirow[t]{2}{*}{ EPE } & Yes & $\begin{array}{l}19 \\
(23,5 \%)\end{array}$ & $\begin{array}{l}29 \\
(35,8 \%)\end{array}$ & $\begin{array}{l}16 \\
(19,8 \%)\end{array}$ & $\begin{array}{l}2 \\
(2,5 \%)\end{array}$ & $\begin{array}{l}4 \\
(4,9 \%)\end{array}$ & $\begin{array}{l}0 \\
(0,0 \%)\end{array}$ & $\begin{array}{l}11 \\
(13,6 \%)\end{array}$ & \\
\hline & No & $\begin{array}{l}125 \\
(61,3 \%)\end{array}$ & $\begin{array}{l}52 \\
(25,5 \%)\end{array}$ & $\begin{array}{l}12 \\
(5,9 \%)\end{array}$ & $\begin{array}{l}5 \\
(2,5 \%)\end{array}$ & $\begin{array}{l}2 \\
(1,0 \%)\end{array}$ & $\begin{array}{l}2 \\
(1,0 \%)\end{array}$ & $\begin{array}{l}6 \\
(2,9 \%)\end{array}$ & \\
\hline \multirow[t]{2}{*}{ PNI } & Yes & $\begin{array}{l}61 \\
(34,7 \%)\end{array}$ & $\begin{array}{l}68 \\
(38,6 \%)\end{array}$ & $(13,1 \%)$ & $\begin{array}{l}2 \\
(1,1 \%)\end{array}$ & $\begin{array}{l}4 \\
(2,3 \%)\end{array}$ & $\begin{array}{l}2 \\
(1,1 \%)\end{array}$ & $\begin{array}{l}16 \\
(9,1 \%)\end{array}$ & \\
\hline & No & $\begin{array}{l}83 \\
(76,1 \%)\end{array}$ & $\begin{array}{l}13 \\
(11,9 \%)\end{array}$ & 5 & $\begin{array}{l}5 \\
(4,6 \%)\end{array}$ & $\begin{array}{l}2 \\
(1,8 \%)\end{array}$ & $(0,0 \%)$ & $\begin{array}{l}1 \\
(0,9 \%)\end{array}$ & \\
\hline \multirow[t]{2}{*}{ LVI } & Yes & $1(4,3 \%)$ & $5(21,7 \%)$ & $7(30,4 \%)$ & $2(8,7 \%)$ & $0(0,0 \%)$ & $0(0,0 \%)$ & $8(34,8 \%)$ & \\
\hline & No & $\begin{array}{l}143 \\
(54,6 \%)\end{array}$ & $\begin{array}{l}76 \\
(29,0 \%)\end{array}$ & $\begin{array}{l}21 \\
(8,0 \%)\end{array}$ & $\begin{array}{l}5 \\
(1,9 \%)\end{array}$ & $\begin{array}{l}6 \\
(2,3 \%)\end{array}$ & $\begin{array}{l}2 \\
(0,8 \%)\end{array}$ & $\begin{array}{l}9 \\
(3,4 \%)\end{array}$ & \\
\hline \multirow[t]{2}{*}{ SVI } & Yes & $1(3,0 \%)$ & $10(30,3 \%)$ & $12(36,4 \%)$ & $0(0,0 \%)$ & $2(6,1 \%)$ & $0(0,0 \%)$ & $8(24,2 \%)$ & \\
\hline & No & $\begin{array}{l}143 \\
(56,7 \%)\end{array}$ & $\begin{array}{l}71 \\
(28,2 \%)\end{array}$ & $\begin{array}{l}16 \\
(6,3 \%)\end{array}$ & $\begin{array}{l}7 \\
(2,8 \%)\end{array}$ & $\begin{array}{l}4 \\
(6,1 \%)\end{array}$ & $\begin{array}{l}2 \\
(0,8 \%)\end{array}$ & $\begin{array}{l}9 \\
(3,6 \%)\end{array}$ & \\
\hline \multirow[t]{2}{*}{ HGPIN } & Yes & $86(47,0 \%)$ & $61(33,3 \%)$ & $19(10,4 \%)$ & $5(2,7 \%)$ & $3(1,6 \%)$ & $0(0,0 \%)$ & $9(4,9 \%)$ & \\
\hline & No & $\begin{array}{l}58 \\
(56,9 \%)\end{array}$ & $\begin{array}{l}20 \\
(19,6 \%)\end{array}$ & $\begin{array}{l}9 \\
(8,8 \%)\end{array}$ & $\begin{array}{l}2 \\
(2,0 \%)\end{array}$ & $\begin{array}{l}3 \\
(2,9 \%)\end{array}$ & $\begin{array}{l}2 \\
(2,0 \%)\end{array}$ & $\begin{array}{l}8 \\
(7,8 \%)\end{array}$ & \\
\hline \multirow[t]{2}{*}{ FV } & Yes & $5(11,6 \%)$ & $28(65,1 \%)$ & $6(14,0 \%)$ & $1(2,3 \%)$ & $1(2,3 \%)$ & $0(0,0 \%)$ & $2(4,7 \%)$ & \\
\hline & No & $\begin{array}{l}139 \\
(57,4 \%)\end{array}$ & $\begin{array}{l}53 \\
(21,9 \%)\end{array}$ & $\begin{array}{l}22 \\
(9,1 \%)\end{array}$ & $\begin{array}{l}6 \\
(2,5 \%)\end{array}$ & $\begin{array}{l}5 \\
(2,1 \%)\end{array}$ & $\begin{array}{l}2 \\
(0,8 \%)\end{array}$ & $\begin{array}{l}15 \\
(6,2 \%)\end{array}$ & \\
\hline TOTAL & TOTAL & $\begin{array}{l}144 \\
(50,5 \%)\end{array}$ & $\begin{array}{l}81 \\
(28,4 \%)\end{array}$ & $\begin{array}{l}28 \\
(9,8 \%)\end{array}$ & 7 & $\begin{array}{l}6 \\
(2,1 \%)\end{array}$ & $\begin{array}{l}2 \\
(0,7 \%)\end{array}$ & $\begin{array}{l}17 \\
(6,0 \%)\end{array}$ & \\
\hline
\end{tabular}

(SMP: Surgical margin positivity, EPE: Extraprostatic extension, PNI: Perineural invasion, LVI: Lymphovascular invasion, SVI: Seminal vesicle invasion, HGPIN: High-grade prostatic intraepithelial neoplasia, FV: Foamy variant)

Table 2. Biopsy Gleason score and radical prostatectomy Gleason score compatibility results.

\begin{tabular}{llllll}
\hline Year & Year & GLEASON SCORE & GLEASON SCORE & GLEASON SCORE & GLEASON SCORE \\
\hline & & Same & Lower & Higher & Total \\
2009 & 2009 & 22 & 8 & 4 & 34 \\
2010 & 2010 & 28 & 13 & 2 & 43 \\
2011 & 2011 & 26 & 11 & 3 & 40 \\
2012 & 2012 & 20 & 11 & 1 & 32 \\
2013 & 2013 & 15 & 6 & 1 & 22 \\
2014 & 2014 & 14 & 9 & 1 & 24 \\
2015 & 2015 & 15 & 13 & 0 & 28 \\
2016 & 2016 & 15 & 9 & 3 & 27
\end{tabular}




\begin{tabular}{llllll}
\hline Year & Year & GLEASON SCORE & GLEASON SCORE & GLEASON SCORE & GLEASON SCORE \\
\hline 2017 & 2017 & 20 & 9 & 6 & 35 \\
Total & $\mathrm{N}$ & 175 & 89 & 21 & 285 \\
& $\%$ & 61,4 & 31,2 & 7,4 & 100 \\
\hline
\end{tabular}

Table 3. The Gleason score distribution and statistical analysis of histopathological patterns in terms of biochemical recurrence.

\begin{tabular}{|c|c|c|c|c|c|c|c|c|}
\hline $\begin{array}{l}\text { HISTOPATH } \\
\text { PATTERNS }\end{array}$ & $\begin{array}{l}\text { OHCFALGCAN } \\
\text { SCORE }\end{array}$ & $\begin{array}{l}\text { GLEASON } \\
\text { SCORE }\end{array}$ & $\begin{array}{l}\text { GLEASON } \\
\text { SCORE }\end{array}$ & $\begin{array}{l}\text { GLEASON } \\
\text { SCORE }\end{array}$ & $\begin{array}{l}\text { GLEASON } \\
\text { SCORE }\end{array}$ & $\begin{array}{l}\text { GLEASON } \\
\text { SCORE }\end{array}$ & $\begin{array}{l}\text { Univariate } \\
\text { analysis } \\
-\mathrm{p}^{*}\end{array}$ & $\begin{array}{l}\text { Multivi } \\
\text { analysi } \\
-\mathrm{p}^{* *}\end{array}$ \\
\hline $\begin{array}{l}\text { Gleason } \\
\text { Pattern } \\
4\end{array}$ & $3+4$ & $4+3$ & $4+4$ & $4+4$ & $4+5$ & TOTAL & & \\
\hline $\begin{array}{l}\text { Poorly } \\
\text { formed }\end{array}$ & 31 & 13 & 3 & 3 & 3 & 50 & $\mathrm{p}>0.05$ & $\mathrm{p}=0.14$ \\
\hline Fused & 76 & 18 & 1 & 1 & 2 & 98 & $\mathrm{p}>0.001$ & $\mathrm{p}=0.04$ \\
\hline Glomeruloid & 6 & 1 & 0 & 0 & 0 & 7 & $\mathrm{p}>0.05$ & $\mathrm{p}=0.67$ \\
\hline Cribriform & 40 & 24 & 6 & 6 & 16 & 88 & $\mathrm{p}>0.001$ & $\mathrm{p}<0.00$ \\
\hline $\begin{array}{l}\text { Gleason } \\
\text { Pattern } \\
5\end{array}$ & $3+5$ & $5+3$ & $5+3$ & $4+5$ & $4+5$ & TOTAL & & \\
\hline $\begin{array}{l}\text { Cribriform } \\
\text { with } \\
\text { comedonecros }\end{array}$ & 1 & 0 & 0 & 8 & 8 & 9 & $\mathrm{p}>0.001$ & $\mathrm{p}=0.64$ \\
\hline Sheets/cords & 4 & 1 & 1 & 8 & 8 & 13 & $\mathrm{p}>0.001$ & $\mathrm{p}<0.00$ \\
\hline Solid & 5 & 2 & 2 & 9 & 9 & 16 & $\mathrm{p}>0.001$ & $\mathrm{p}<0.00$ \\
\hline $\begin{array}{l}\text { Single } \\
\text { cell } \\
\text { infiltration }\end{array}$ & 1 & 0 & 0 & 7 & 7 & 8 & $\mathrm{p}>0.001$ & $\mathrm{p}=0.34$ \\
\hline
\end{tabular}

$\left({ }^{*}\right.$ Chi-square test was used in the univariate analysis.

**Logistic regression analysis was performed in the multivariate analysis.)

Table 4. The comparison of histopathological parameters and biochemical recurrence status.

\begin{tabular}{|c|c|c|c|c|c|c|c|}
\hline & \multicolumn{7}{|c|}{$\begin{array}{l}\text { BIOCHEMICABIOCHEMICABIOCHEMICABIOCHEMICAL } \\
\text { RECURRENCRECURRENCRECURRENCERECURRENCE }\end{array}$} \\
\hline & No & No & Yes & Yes & Yes & $\begin{array}{l}\text { Univariate } \\
\text { analysis } \mathrm{p}^{*}\end{array}$ & $\begin{array}{l}\text { Multivariate } \\
\text { analysis } \\
\mathrm{p}^{* *}\end{array}$ \\
\hline & $\mathbf{N}$ & $\%$ & $\mathbf{N}$ & $\%$ & $\%$ & & \\
\hline \multicolumn{8}{|c|}{$\mathrm{EPE}$} \\
\hline No & 151 & 80,3 & 53 & 54,6 & 54,6 & $<0,001$ & $<0.001$ \\
\hline Yes & 37 & 19,7 & 44 & 45,4 & 45,4 & & \\
\hline \multicolumn{8}{|c|}{ SMP } \\
\hline No & 120 & 63,8 & 23 & 23,7 & 23,7 & $<0,001$ & $<0.001$ \\
\hline Yes & 68 & 36,2 & 74 & 76,3 & 76,3 & & \\
\hline
\end{tabular}




\begin{tabular}{|c|c|c|c|c|c|c|c|}
\hline \multirow[b]{2}{*}{ PNI } & \multicolumn{7}{|c|}{$\begin{array}{l}\text { BIOCHEMICABIOCHEMICABIOCHEMICABIOCHEMICAL } \\
\text { RECURRENCRECURRENCRECURRENCERECURRENCE }\end{array}$} \\
\hline & & & & & & \multirow{4}{*}{$<0,001$} & \multirow{4}{*}{$\mathrm{p}=0.382$} \\
\hline No & 87 & 46,3 & 22 & 22,7 & 22,7 & & \\
\hline Yes & 101 & 53,7 & 75 & 77,3 & 77,3 & & \\
\hline \multicolumn{6}{|l|}{ LVI } & & \\
\hline No & 182 & 96,8 & 80 & 82,5 & 82,5 & \multirow[t]{3}{*}{$<0,001$} & \multirow[t]{3}{*}{$\mathrm{p}=0.160$} \\
\hline Yes & 6 & 3,2 & 17 & 17,5 & 17,5 & & \\
\hline \multicolumn{6}{|l|}{ SVI } & & \\
\hline No & 184 & 97,9 & 68 & 70,1 & 70,1 & \multirow[t]{3}{*}{$<0,001$} & \multirow[t]{3}{*}{$<0.001$} \\
\hline Yes & 4 & 2,1 & 29 & 29,9 & 29,9 & & \\
\hline \multicolumn{6}{|c|}{ HGPIN } & & \\
\hline No & 72 & 38,3 & 30 & 30,9 & 30,9 & \multirow[t]{3}{*}{0,219} & \multirow[t]{3}{*}{$\mathrm{p}=0.141$} \\
\hline Yes & 116 & 61,7 & 67 & 69,1 & 69,1 & & \\
\hline Total & 188 & 100 & 97 & 100 & 100 & & \\
\hline
\end{tabular}

(EPE: Extraprostatic extension, SMP: Surgical margin positivity, PNI: Perineural invasion, LVI: Lymphovascular invasion, SVI: Seminal vesicle invasion, HGPIN: High-grade prostatic intraepithelial neoplasia ${ }^{*}$ Chisquare test was performed in the univariate analysis. ${ }^{* *}$ Logistic regression analysis was performed in the multivariate analysis.)

\section{Figure Legends}

Figure 1. The histomorphological appearances of Gleason pattern 4 glands.

a. Poorly-formed (H\&E 200x) b. Fused (H\&E 200x) c. Cribriform (H\&E 100x) d. Glomeruloid (H\&E 400x)

Figure 2. The histomorphological appearances of Gleason pattern 5 glands.

a. Cribriform with comedonecrosis (H\&E 100x) b.Sheets/cords (H\&E 100x) c.Solid areas (H\&E 100x) d. Single-cell infiltration (H\&E 100x)

Figure 3. Biochemical recurrence-free survival curves of the prostate cancer patients stratified for radical prostatectomy Gleason scores and Grade Groups (overall log-rank $\mathrm{p}<0.001$ ).

Figure 4. Biochemical recurrence-free survival curve of the prostate cancer patients stratified for pathological stage $(\log -$ rank $\mathrm{p}<0.001)$.

Figure 5. Biochemical recurrence-free survival curves of the prostate cancer patients stratified for extraprostatic extension (log-rank $\mathrm{p}<0.001$ ), perineural invasion (log-rank $\mathrm{p}<0.001)$, lymphovascular invasion $(\log$-rank $\mathrm{p}<0.001)$, surgical margin positivity $(\log$-rank $\mathrm{p}<0.001)$, high grade prostatic intraepithelial neoplasia (log-rank p $>0.05)$, and tumor volume $(\log$-rank $\mathrm{p}<0.001)$.

Figure 6. Biochemical recurrence free survival curve of the prostate cancer patients stratified for the presence of cribriform glands $(\log -$ rank $\mathrm{p}<0.001)$. 


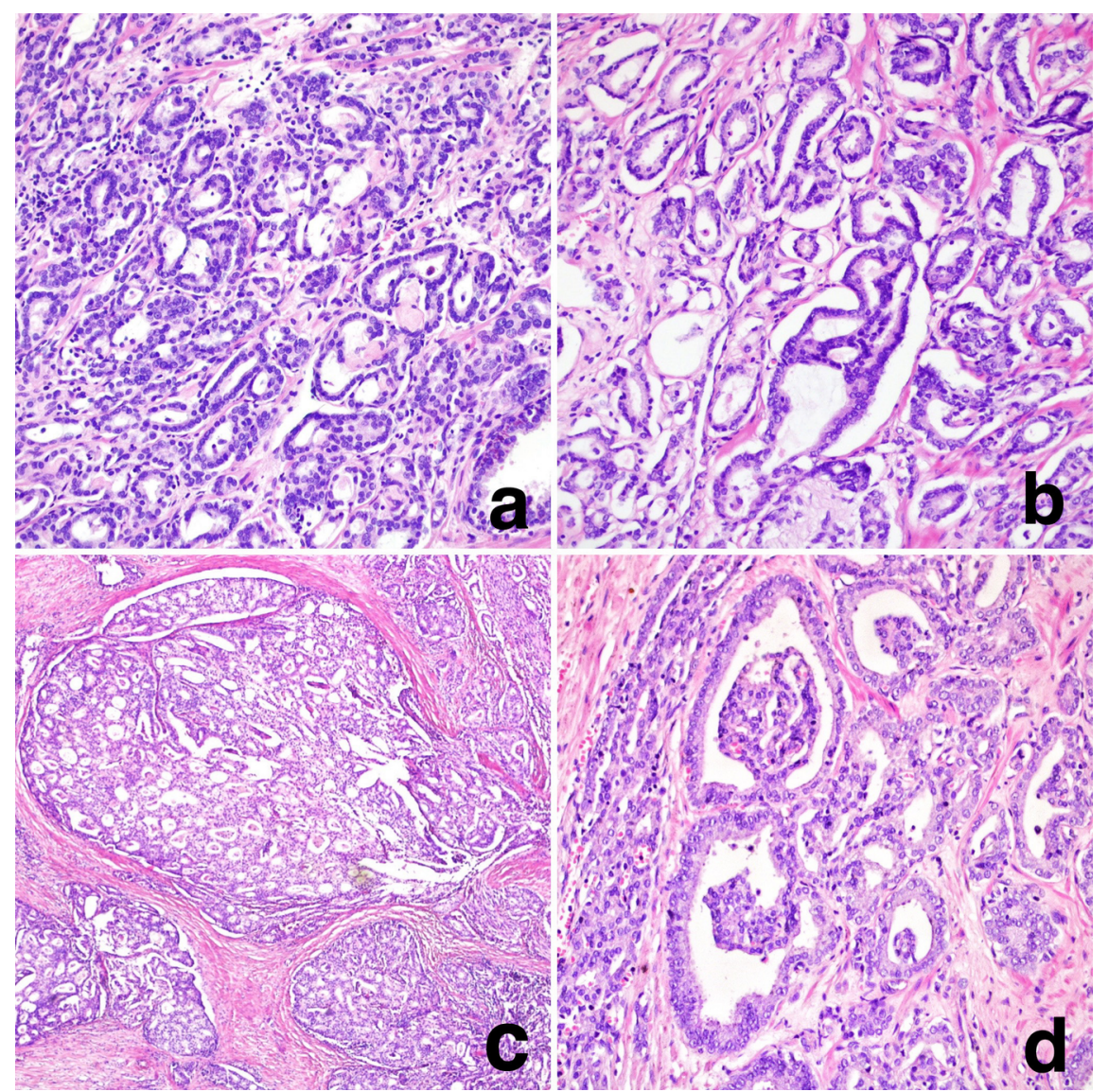



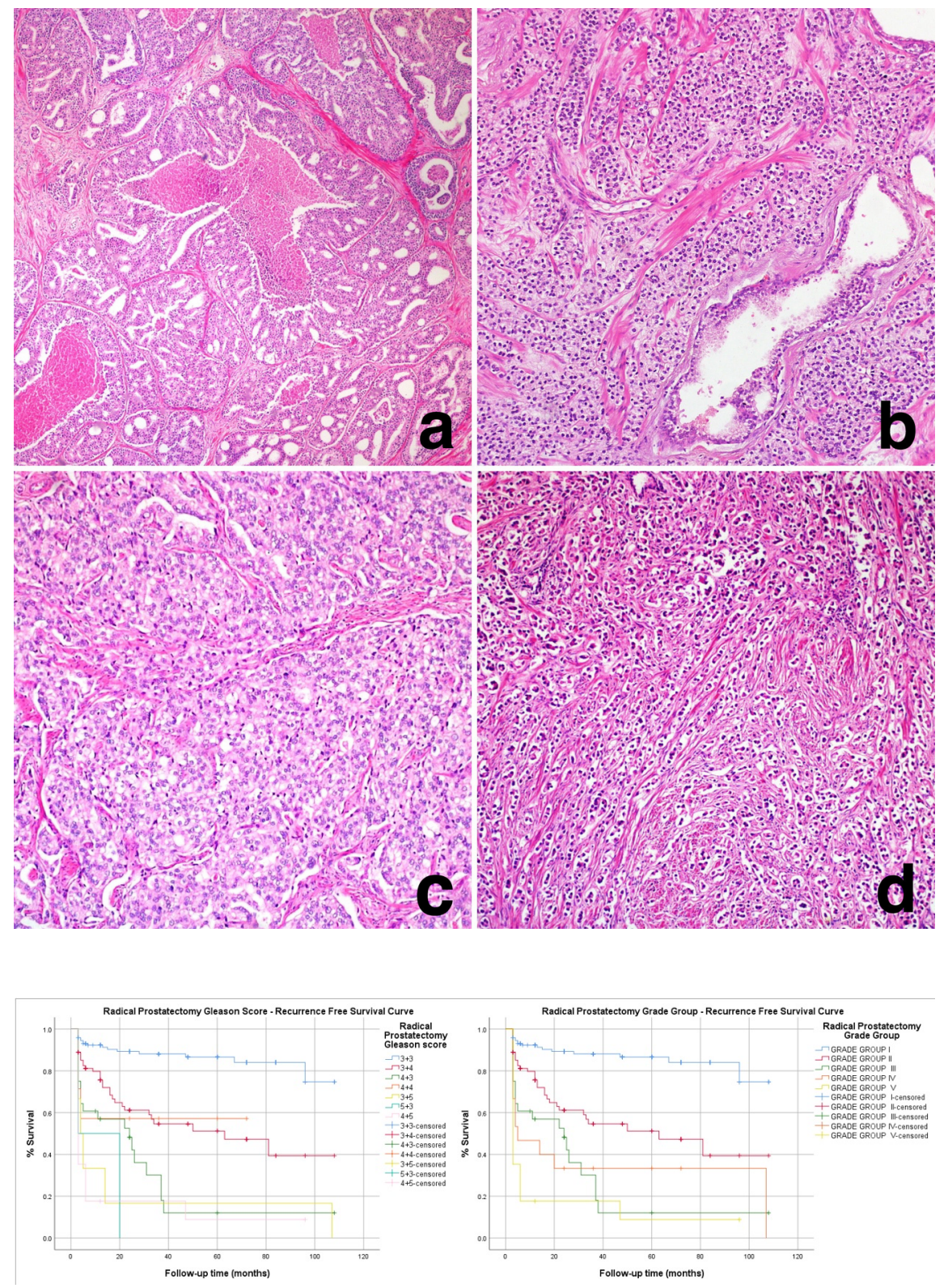

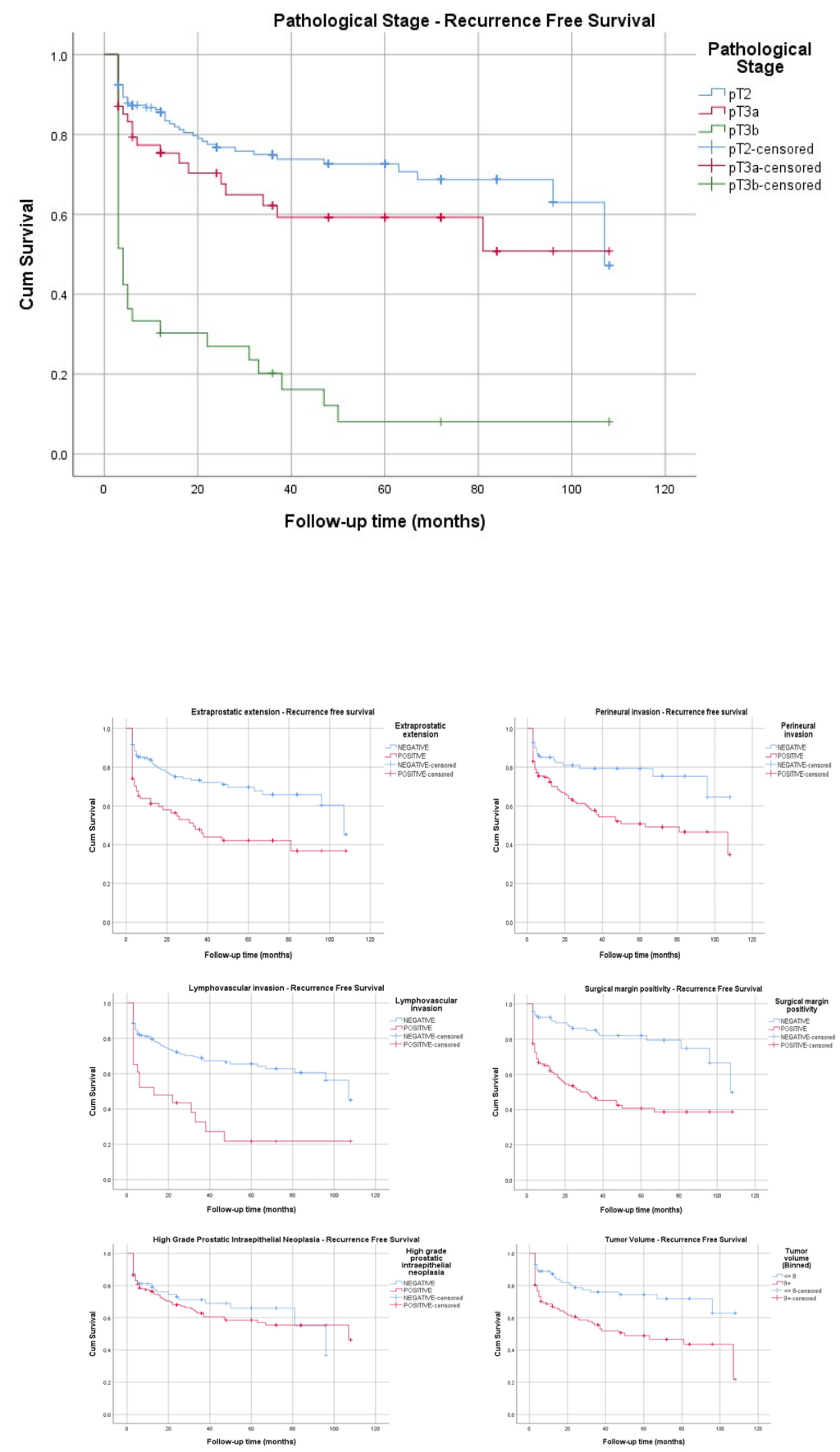


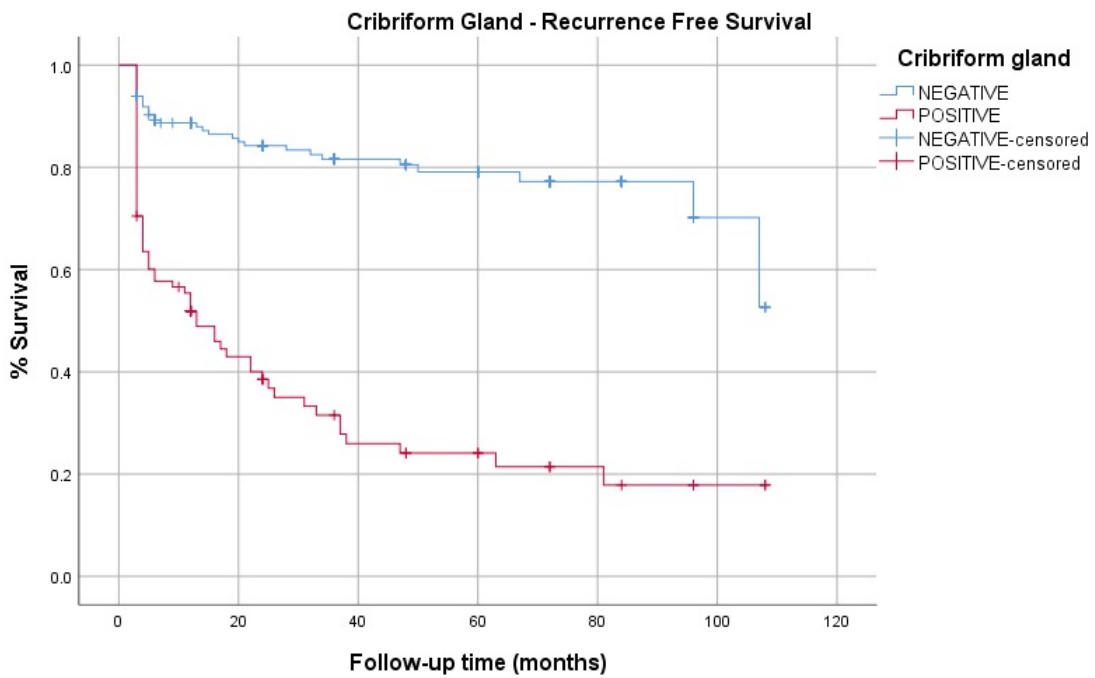

